\title{
Russian as a Foreign Language Interview Test for Russian Federation Citizenship Applicants: Structure and Content
}

\author{
Angela Victorovna Dolzhikova
}

Victoria Borisovna Kurilenko

Anna Sergeevna Ivanova

Natalia Vladimirovna Pomortseva

Ekaterina Yurievna Kulikova

Peoples' Friendship University of Russia, Moscow, Russian Federation Email: viktoria101961@mail.ru

\section{Doi:10.5901/mjss.2015.v6n4s4p93}

\section{Abstract}

The introduction of a simplified procedure for obtaining citizenship by persons who are native Russian speakers became a promising innovation in the migration policy of the Russian Federation. The status of native Russian speaker is granted to foreign citizens and persons without citizenship that have passed the interview test. At the present time, a new form of the Russian language exam is already being conducted in a number of testing centres within the Russian Federation, and three exam models have become widely used. In connection with that, the relevant tasks of Russia's current testing practice are as follows: identifying the nature and specifics of the "linguo-didactic interview test of Russian as a foreign language" concept; linguo-didactic analysis and evaluation of the existing models; experimental verification of their effectiveness, testing validity and evaluating materials contained in each model; development and validation of a new complex model of interview tests of Russian language for foreigners applying for citizenship of the Russian Federation. Possible ways of solving those relevant issues are proposed in this article.

Keywords: test of Russian as a foreign language, integration exam, test for obtaining the status of a native Russian speaker, interview test

\section{Introduction}

At the present time, the Russian Federation (RF) is one of the largest countries receiving migration flows. According to the data from the Federal Migration Service (FMS) of Russia, over the first five months of 2015, 7,737,743 foreign citizens arrived in the RF, 135,059 of which were granted a temporary residence permit, 55,751 obtained permanent residency and 72,222 obtained citizenship of the Russian Federation. Over that period, 69,330 compatriots and their family members arrived in the Russian Federation and registered with the FMS of Russia (according to the data from the official FMS website www.fms.gov.ru).

Over the last decade, the scope of Russian immigration has shown a stable increase and shows a tendency for further growth, which is explained by the Russian Federation's need to acquire a larger workforce pool; different economic growth rates for countries in the Eurasian region; the priorities of Russia's national migration policy, including the following key points: to create an environment and stimulus for compatriots living abroad and certain categories of foreign citizens to acquire permanent residency in the Russian Federation (Report, 2014); to create an environment to assist with migrants' successful adaptation and integration; to protect their rights and freedoms; to provide social security (Concept..., 2025), etc.

The new promising tendencies in the migration policy of the RF include the possibility of using a simplified procedure for obtaining citizenship of the RF, by foreigners recognized as native Russian speakers (About making amendments to... №71-FZ, 2014), i.e. having communication competence corresponding to certification level IV. A person is recognized as a native Russian speaker based on the results of an interview conducted by a special commission (About making amendments to... №71-FZ, 2014). The simplified procedure for obtaining citizenship of the Russian Federation is regulated by Federal Law № 71 "About making amendments to the FZ "About the citizenship of the 
Russian Federation" signed by President of the Russian Federation V.V. Putin on 20 April, 2014.

Since the law came into effect on 1 May, 2014, the linguo-didactic interview test of Russian as a foreign language (LIT RFL) has been conducted at a number of testing centres. That has, on the one hand, allowed for the accumulation of certain amount of experience in conducting evaluation tests in the new format, but on the other hand, has revealed the need to perform linguo-didactic analyses on the established models of testing, the selection of promising technologies and advanced practices and the development of a systemic methodological and methodical basis for the LIT RFL, including determining its essential characteristics and specifics, identifying its main structural components, types and content of test tasks, etc. This article proposes possible ways of analyzing and developing the RFL system by solving the following issues:

1. Development of a system based around the author's definition of the LIT RFL.

2. Linguo-didactic analysis of the models related to Russian as a foreign language (RFL) interview tests of that are most widely used for obtaining citizenship of the Russian Federation via the simplified procedure.

3. Describing and developing a system related to the author's model of the LIT RFL.

4. Experimental verification highlighting the effectiveness and usability of the mentioned models of interview tests of RFL.

\section{Literature Review}

This section demonstrates how the model interview test proposed in this article relates to currently existing models used both in Russia and abroad, and it potential performance relative to the established State testing system of the Russian Federation.

At its current stage, the State testing system of Russia has been expanded to include new components; an integration exam of Russian and sections covering Russian history and the fundamentals of the legislation of the Russian Federation. In accordance with decree № 602 "About providing international consent" of 7 May, 2012, issued by the President of the Russian Federation, on 1 January 2015 the integration exam was introduced for foreign citizens wishing to obtain temporary residency permits, permanent residency or working permits. To further this, an academic and methodical basis for preparing and conducting these exams was developed and the following materials were developed: the concept of the exam (Dolzhinkova, Moseikina, Kozmenko, Kiseleva, Kazhaeva, 2014), exam requirements for different categories of foreign citizens; methodical editions for examiners, preparation textbooks for foreign citizens covering the modules "History of Russia" and "Fundamentals of legislation of the RF". Emphasizing socio-cultural and adaptation aspects of communication and integration preparation by foreign citizens and persons without citizenship are required to develop new textbooks and practice tests for Russian as foreign language (Balykhina and Rumyantseva, 2014; Pomortseva and Krotova, 2015; et al.). The methodical basis for the integration exam was expanded with reference books, brief reference brochures and included audio and video courses for foreign citizens.

The multi-level Russian testing system for Russian as a foreign language (TRFL), developed by the Lomonosov State Moscow University, Pushkin State Russian Language Institute, the Peoples' Friendship University of Russia and the Saint-Petersburg State University, allows one to determine the level of Russian communication competence of foreign citizens, unifies the requirements to the contents for teaching RFL, promotes international recognition of Russian certificates and its corresponding certification system as well as Russia's integration into the European educational space. The system's developers relied on the vast theoretical, academic and methodical bases established through the theory and practice of teaching RFL in Russia over the last 60 years (Andrushina, Balykhina, Klobukova et. al.), as well as being based on international experience gained by testing and teaching foreign languages. By 1998, the six-level test system for Russian as a foreign language was developed, evaluated and described, and the state standards and requirements regarding education were adopted (Educational standards... ,1998; Balykhina, Klobukova, Stepanenko, 2007; Boitsov, Nesterova, Yurkov, 1998; Andrushina, Vladimirova, Klobukova, Ivanova, Gapochka, Kurilenko et al., 2000); Gapochka, Kuilenko, Titova, 2005; et al.). In 1997, the system was officially recognized by the ALTE (Association of Language Testers of Europe). At present, the system of tests for Russian as a foreign language (TORFL) is recognized as being equivalent to the European system of levels of foreign language proficiency. It includes six levels that correlate with the CEFR - Common European Framework of Reference (Common European Framework of Reference (2003)) and is widely used in the practice of teaching Russian as a foreign language both at home and abroad. In 2003, the test was developed as a part of the system for obtaining Russian Federation citizenship (Afanasieva, Balykhina, Elnikova, Ivanova, Isaev, Klobukova, Korchagina, Kostina, Rumyantseva, Stepanenko, Tolstykh, 2003).

During the development of the Russian linguo-didactic interview test model for foreign citizens applying for Russian citizenship, the existing testing methods, developed abroad, were analyzed to verify their effect and usability in citizenship 
testing (Clark and Clifford 1988; Douglas, 1994; Fulcher, 1996; Hiple, 1987; Lazaraton, 1996; Stansfield and Kenyon, 1992; van Lier, 1989; Wigglesworth, 1997; Young, R. and He, 1998; et al.). The American experience of using pragmatic testing of verbal communication competence in the form of an interview test was studied, including the structure of the interview test, procedures for conducting said tests, evaluations and questions for tester preparation. (Thompson, 1990). The development of the concept of linguo-didactic interview tests (Dolzhnikova, Kurilenko, Ivanova, Pomortseva) became a logical continuation of the development of State testing systems in the Russian Federation. The academic and methodical content of new components in the testing system permitted the proposal of an original model for conducting a Russian as a foreign language interview test for foreign citizens applying for the citizenship.

\section{Linguo-didactic Analysis of Prevalent Models of RFL Interview Tests}

In order to fully understand the current key models of RFL tests a survey of the employees from testing centres in the RF revealed that at the present time, there are three key models of LIT RFL.

Model 1. Testing consists of a single stage and represents a conversation on social, everyday and socio-cultural topics. The conversation includes 30 questions, lasts no more than 30 minutes, and is conducted in the form of reactive replication. The testee mostly plays a responsive and reactive communication role.

It appears that this model of LIT RFL fails to be an effective instrument in evaluating knowledge of the language system, expressive means, strategies and tactics of speech sufficient for the corresponding level IV certification. In addition, this model lacks sufficient criterial validity: making the task of formalizing the evaluation of language competence, which is the basic component of communication competence, seemingly impossible. Moreover, according to examiners' reviews, the overall communication competence of a large number of candidates who failed was lower than Level I, which brought an unreasonably high load on the commission for recognizing native speakers. The examiners, who have experience of working with this model, recommended the addition of a special "qualification stage", which would evaluate the language competence level of candidates (for vocabulary and grammar certification level IV) and eliminate the persons with poor or limited knowledge of Russian, essentially those whose language skills signified them as a potential automatic failure, out of the evaluation procedure.

Model 2. The test consists of a single stage divided into two parts: a) essay writing on a given socio-cultural topic (30 min.), b) topical conversation related to one of the issues mentioned by the testee in his or her essay (15 min.). The topical conversation proposed in this model has the same linguo-didactic characteristics as the ones of Model 1. In our opinion, this model of test evaluation also fails to provide a justified evaluation of the level of RFL: strategies and tactics of communication on social and everyday topics are not evaluated; the range of communicative and behavioral roles of the testee, which could be included in these kind of test tasks, are quite limited; content-related issues and the criterial validity of the test and its efficiency also causes certain doubts and raises questions as to its effectiveness.

Model 3. The test consists of two stages. The first stage is related to qualification and fulfills a selective function identifying candidates who have little or no knowledge of Russian. Any person or persons who fail the first qualification stage are not advanced to the second stage, which is the form of an interview. The first stage uses a matrix test consisting of 30 tasks and is aimed at evaluating language competence (knowledge of Russian vocabulary and grammar). The test lasts 30 minutes. The second stage is a 30-minute topical conversation in the form of reactive replication. The advantages of this model include criterial validity, functionality and efficiency. However, at the same time, this form of test evaluation fails to fully evaluate a strategic component of the testee's communication competence and does not allow the speech and communication material, corresponding to certification level IV of RFL, to be sufficiently covered.

\section{The Suggested Complex Model for an RFL Interview Test}

Analysis of the models currently used in the practice of testing, identifying its positive characteristics, understanding longterm experience in teaching and testing for RFL have allowed the authors to create and offer up for discussion a new model of didactic test of Russian as a foreign language, in the form of an interview for foreigners applying for citizenship of the Russian Federation. We will dwell upon its basic structural and content characteristics to provide a greater understanding of its functionality and usability.

Since the lingvo-didactic test of RFL takes the form of an interview in this article, we refer to the comprehensive criterion-oriented means of measuring the communicative competence of foreigners exercised in the form of specially organized conversations on socio-cultural and social-welfare topics. The content of LIT RFL should fit with the modern socio-and linguo-cultural realities of the Russian-speaking community. The main features of LIT RFL should include 
authenticity for all tests and a shown proximity of test situations to natural conditions of communication as would be found with native Russian speakers.

Lingvo-didactic interview testing for RFL is designed and conducted in accordance with the principle of continuity with the organizational basics, structural and substantive characteristics of the system of migrant integration testing and of the state system of testing Russian as a foreign language. In this context, the main objectives of linguo-didactic interview testing are recognized as the integration of migrants into Russian society, protecting their rights and freedoms and ensuring social security. Lingvo-didactic test interviews for Russian as a foreign language (level C2) are developed in parallel with the material, containing social and cultural significance, which allows through the process of preparation and test pass success rates to form a cognitive system for a foreigner applying for citizenship of the Russian Federation, on a value-oriented basis which presupposes successful adaptation to Russian society.

LIT RFL consists of two parts: the subtest "Language competence" and the subtest "Communicative competence." Test tasks are developed using authentic language, speech and communication materials; test situations are as close as possible to the conditions of natural communication as encountered by native Russian language speakers. Test materials are designed to meet the requirements of ethnic and socio-cultural correctness and tolerance whereby the linguo-cultural part mostly corresponds to the realities of contemporary social, political and cultural practices of Russian society.

Lingvo-didactic testing of Russian as a foreign language is carried out in two stages:

Stage I - "stage of admission" - aims at checking the level of language competence of foreign citizens. At this stage a matrix type test is proposed for the testees. It includes closed tasks, tests to establish the conformity, close-tests. The validity of the present subtest is determined by the control matrix. The subtest "Language competence" includes 30 tasks with a runtime of 30 minutes. The implementation of this phase of testing is methodically justified because it provides criterion validity of the test, as well as serving as a filter to cut off those whose language competence does not match the level of verification. In order to advance to this second stage a pass rate of at least $66 \%$ is required. This level of linguistic competence allows testees to perform tasks of the second stage.

Stage II aims to control the level of communicative and lingvo-cultural competence formation of the testee.

The stage II subtest "Communicative competence" is a thematic discussion with lingvo-cultural orientation. The main objectives of this subtest are to determine the ability of testees:

a) To act in different social, behavioral and communication roles (the initiator of communication, communicative leader, etc.);

b) To implement communication strategies that correspond to the scope of the main characteristics and situations of communication, types of discursive interaction (institutional / non-institutional discourse);

c) To quickly change communication strategies as and when the features within the situation of communication and discursive interaction are changed;

d) To use the necessary amount of lingvo-cultural knowledge, skills and abilities appropriate to given communication situations.

The subtest "Communicative competence" consists of three thematic areas:

1. Man and Society.

2. Man and Culture.

3. Person to person (personal communication).

The subtest "Communicative competence" consists of 3 units of tasks. The first unit of tasks is reactive replication. Tasks of this unit are general, alternative, public and private identification questions, etc. Testees serve in a responsive communicative role, demonstrating possession of communication strategies in the format of "a monologue in the dialogue."

The second unit of tasks is, through its structure and content, a test in the form of a guided discussion. Tasks of this unit are problem type questions. Testees must demonstrate a level of proficiency in strategies of persuasion, protection of one's point of view, opinion, etc., playing the responsive communicative role of participant in dialogueunison, dissonance, etc. During the realization of the second unit of tasks audio and video usage is recommended.

Tasks of the third unit are communicative case studies (cases). Testees act as an initiator of communication, demonstrating possession of speech influence strategies, explanations, etc. in social-welfare and socio-cultural spheres. Run time for the subtest "Communicative competence" - 30 minutes.

The set of exam materials includes:

- An introductory explanatory note summarizing the structure of the exam, rules of conduct, indications of the scale of assessments and the minimum passing score;

- The subtests "Language competence" and "Communicative competence", contain subtest instructions of quantitative parameters (time, maximum score, number of tasks, etc.) and instructions for execution; 
- Guidelines for each subtest, including a description of the objectives, tasks, evaluation process, procedures for subtest task execution and the evaluation of results;

- An annex containing the control matrix for the subtest "Language competence" and a piece of expert review related to the subtest "Communicative competence."

\section{Research of RFL Interview Test Model Efficiency}

\subsection{Participants}

The study involved 80 1st year students from the Russian People's Friendship University, who were combined into two groups: experimental (EG) and control (CG). Each group was subdivided into 4 groups corresponding to the number of LTI RFL models set as the object of study. Into the experimental group 40 students were invited, 10 of which were citizens of the Ukraine ( 6 men and 4 women), 10 from Kazakhstan ( 5 men and 5 women), 10 from Uzbekistan ( 7 men and 3 women) and 10 from Tajikistan ( 5 men and 5 women). The choice of countries was made corresponding with the fact that they are, traditionally, the leaders in terms of migration flow to Russia, but from Russian lingvo-cultural environments representing different degrees (with the highest in Ukraine and the lowest in Tajikistan). Each experimental subgroup (ES) uniformly included representatives from these foreign countries. The criteria for selection into the experimental group were: a) the presence of close relatives (one or both parents, grandparents), who had previously resided in territory belonging to the Soviet Union, within the state border of the Russian Federation; b) knowledge of Russian language and its everyday use in social-welfare and socio-cultural spheres.

The control group consisted of 40 students (22 men and 18 women), who are citizens of the Russian Federation and, accordingly, have a command of the Russian language on a native speaker level. The control group, as mentioned above, also included four subgroups (CS) with 10 students who are citizens of the Russian Federation.

The study was also attended by 20 employees of the testing centers in Moscow and the Moscow region from the 35 - 55 age range (18 women, 2 men) who hold a Russian language teaching diploma and have least 5 years work experience in data centers.

\subsection{Research procedure}

The study was conducted in two stages:

1. The objective of the first stage was to determine the validity of the 4 lingvo-didactic test models of Russian as a foreign language in interview format ( 3 current and 1 complex proposed by the authors of this article). This stage included two sub stages: during the first sub stage students passed a lingvo-didactic test of RFL, in interview format, with 4 versions of control-measuring materials, corresponding to checked models. Each of the four models of LIT RFL were tested in one experimental and one control subgroup. During the second sub stage students completed the RFL test, developed on the basis of the level IV certification "Sample test of RFL" (Averyanova, Belikova, Yerofeyeva, 2000). Successful completion of the "Sample test" at this level "indicates a high level of proficiency in Russian, close to the level of a native speaker" (Ibid). This regulatory document, approved by the Ministry of Education and Science of the Russian Federation and recommended for use in the State system of testing Russian as a foreign language, has for 15 years been actively and successfully used in testing centers within Russia. Its reliability, validity and efficiency are recognized by the Russian educational community. The results, received by testees following successful completion of this test, were used as controls when assessing the validity of the CMM checked LIT RFL models.

2. The objective of the second stage of the study was to identify the evaluation of LIT RFL model execution by testing teaching center staff i.e. Russian as a foreign language teachers.

\subsection{Instruments}

During the study, the following instruments were used:

1. For the handling of the first sub stage:

- Control-measuring materials (CMM) for the implementation of the 3 lingvo-didactic RFL interview format test models, which were used during the year in a number of testing centers within the Russian Federation.

- Control-measuring materials for the realization of the complex (the author's) model lingvo-didactic test of 
Russian as a foreign language in interview format.

2. For the second sub stage of the study the Russian as a foreign language test (level IV certification. General command) was used, developed on the basis of the "Sample test of RFL" (Averyanova, Belikova, Yerofeyeva, 2000).

3. In carrying out the second stage, the aim of which was to identify the assessment of patterns within the interview format RFL lingvo-didactic test by testing center staff (qualified RFL teachers), a questionnaire, developed by the authors of this article was used, which includes the following items:

- Authenticity of CMMs: the degree of proximity for test cases, created by the developers, to the conditions of real discursive practice for this cohort of testees;

- Representativness factors of the proposed control-measuring materials: the principles of selection, the degree of communicative value of language, speech and communicative material;

- Content validity: comprehensiveness of language, speech and communicative material corresponding to level IV certification relating to a general command of Russian;

- Construct validity of CMMs: the degree of compliance of testing objects, the nature of tasks for the modern discourse-cognitive model of operating language, speech and communication materials;

- External validity of materials: the level of ethnic and socio-cultural correctness, the degree of compliance for content-related plans to the realities of Russian life in which the testees are going to live and work;

- Reliability: the volume of checked skills and abilities for operating language, speech and communication materials, and the validity of the number of communication problems, as well as the time allotted to complete the test and the methodological validity of the degree of difficulty for included tasks;

- Adaptability: the accessibility and content of the test instructions for this cohort of testees;

- Efficiency: the ability to get the most accurate language, speech and communicative information, for the level of competence of the testees, with methodically correct time expenses;

- Consistency and structural integrity.

\section{Discussion}

\subsection{Analysis of pass results for LIT RFL based on model 1}

Table 1. Pass results for LTI RFL based on model 1 (in \%)

\begin{tabular}{|l|c|c|c|c|c|}
\hline \multirow{2}{*}{ Number of points } & \multicolumn{3}{|c|}{ Results from experimental subgroup 1 } & \multirow{2}{*}{ Results from control sub-group 1 (Russia) } \\
\cline { 2 - 5 } & Ukraine & Kazakhstan & Uzbekistan & Tajikistan & \\
\hline $0-65$ points & 1 & 15 & 27 & 33 & 100 \\
\hline $66-100$ points & 99 & 85 & 73 & 67 & 100 \\
\hline Total: & 100 & 100 & 100 & 100 & 0 \\
\hline
\end{tabular}

Table 2. Pass results for LTI RFL based on the level IV certification sample test

(in \%)

\begin{tabular}{|l|c|c|c|c|c|}
\hline \multirow{2}{*}{ Subtests } & \multicolumn{3}{|c|}{ Results from experimental subgroup 1 } & \multirow{2}{*}{ Results from control sub-group 1 (Russia) } \\
\cline { 2 - 5 } & Ukraine & Kazakhstan & Uzbekistan & Tajikistan & 100 \\
\hline Subtest "Grammar. Vocabulary" & 71 & 67 & 56 & 48 & 98 \\
\hline Subtest "Reading" & 86 & 78 & 67 & 56 & 100 \\
\hline Subtest "Listening" & 85 & 83 & 71 & 61 & 97 \\
\hline Subtest "Writing" & 76 & 85 & 65 & 47 & 100 \\
\hline Subtest "Speaking" & 98 & 86 & 72 & 56 & \\
\hline
\end{tabular}

Note: This table shows the percentage of testees who successfully completed the subtests (66\% and above)

According to the data given in Table 1, testees from all five countries successfully coped with the tests presented through model 1. However, its' with comparing the key figures i.e. grades received in the performance of a sample test (Table 2), which shows significant discrepancies in the results, indicating the lack of validity (checking power) of the controlmeasuring materials of this model. While at the same time, the test results for the control subgroup testees (citizens of Russia) on both models display only minor differences. 


\subsection{Analysis of pass results for LIT RFL based on model 2}

Table 3. Pass results for LIT RFL based on model 2 (in \%)

\begin{tabular}{|l|c|c|c|c|c|}
\hline \multirow{2}{*}{ Number of points } & \multicolumn{4}{|c|}{ Results from experimental subgroup 2 } & \multirow{2}{*}{ Results from control sub-group 2 (Russia) } \\
\cline { 2 - 5 } & Ukraine & Kazakhstan & Uzbekistan & Tajikistan & \\
\hline $\mathbf{0 - 6 5}$ points & 61 & 46 & 51 & 56 & 15 \\
\hline $\mathbf{6 6 - 1 0 0}$ points & 59 & 54 & 49 & 44 & 85 \\
\hline Total: & 100 & 100 & 100 & 100 & 100 \\
\hline
\end{tabular}

Table 4. Pass results for LIT RFL based on the level IV certification sample test

(in \%)

\begin{tabular}{|l|c|c|c|c|c|}
\hline \multirow{2}{*}{ Subtests } & \multicolumn{3}{|c|}{ Results from experimental subgroup 2 } & \multirow{2}{*}{ Results from control sub-group 2 (Russia) } \\
\cline { 2 - 5 } & Ukraine & Kazakhstan & Uzbekistan & Tajikistan & \\
\hline Subtest "Grammar. Vocabulary" & 68 & 69 & 58 & 49 & 100 \\
\hline Subtest "Reading" & 87 & 81 & 69 & 56 & 97,5 \\
\hline Subtest "Listening" & 81 & 85 & 73 & 58 & 99 \\
\hline Subtest "Writing" & 75 & 79 & 64 & 44 & 98 \\
\hline Subtest "Speaking" & 99 & 86 & 76 & 61 & 100 \\
\hline
\end{tabular}

Note: This table shows the percentage of testees who successfully completed the subtests (66\% and above)

Analysis of the data given in Table 3 indicates that representatives from all countries showed lower results than testees of ES 1, during the test of the first model. However, the pass results for the test based on the level IV certification sample test (Table 4) differ slightly from those of ES 1 under similar testing (compare with Table 3). The data acquired by checking the testees of the control subgroup also has significant differences. In this context, it seems that the inclusion of genre specific essays on socio-cultural topics into test materials for written work cannot be considered reasonable.

\subsection{Analysis of pass results for LIT RFL based on model 3}

Table 5. Pass results for LIT RFL based on model 3

(in \%)

\begin{tabular}{|l|c|c|c|c|c|}
\hline \multirow{2}{*}{ Number of points } & \multicolumn{3}{|c|}{ Results from experimental subgroup 3 } & \multirow{2}{*}{ Results from control sub-group 3 (Russia) } \\
\cline { 2 - 5 } & Ukraine & Kazakhstan & Uzbekistan & Tajikistan & \\
\hline $\mathbf{0 - 6 5}$ points & 15 & 21 & 36 & 39 & 0 \\
\hline $\mathbf{6 6 - 1 0 0}$ points & 85 & 79 & 74 & 61 & 100 \\
\hline Total: & 100 & 100 & 100 & 100 & 100 \\
\hline
\end{tabular}

Table 6. Pass results for LIT RFL based on the level IV certification sample test

(in \%)

\begin{tabular}{|l|c|c|c|c|c|}
\hline \multirow{2}{*}{ Subtests } & \multicolumn{3}{|c|}{ Results from experimental subgroup 3 } & \multirow{2}{*}{ Results from control sub-group 3 (Russia) } \\
\cline { 2 - 5 } & Ukraine & Kazakhstan & Uzbekistan & Tajikistan & \\
\hline Subtest "Grammar. Vocabulary" & 72 & 69 & 59 & 46 & 99,5 \\
\hline Subtest "Reading" & 87 & 74 & 65 & 58 & 98 \\
\hline Subtest "Listening" & 86 & 86 & 74 & 60 & 100 \\
\hline Subtest "Writing" & 74 & 79 & 68 & 45 & 97 \\
\hline Subtest "Speaking" & 87 & 78 & 75 & 52 & 100 \\
\hline
\end{tabular}

Note: This table shows the percentage of testees who successfully completed the subtests (66\% and above)

Data highlighted in Tables 5 and 6 show significant differences between the results of testees from ES 3 in passing the test based on model 3 (results shown above) and those based on a standard level IV certification test. From our point of view, the CMMs for model 3 also need to be improved. 


\subsection{Analysis of pass results for LIT RFL based on the complex (authors') model}

Table 7. Pass results for LIT RFL based on the complex (authors') model

(in \%)

\begin{tabular}{|l|c|c|c|c|c|}
\hline \multirow{2}{*}{ Number of points } & \multicolumn{3}{|c|}{ Results from experimental subgroup 4 } & \multirow{2}{*}{ Results from control sub-group 4 (Russia) } \\
\cline { 2 - 5 } & Ukraine & Kazakhstan & Uzbekistan & Tajikistan & 0 \\
\hline $\mathbf{0 - 6 5}$ points & 19 & 21 & 32 & 45 & 100 \\
\hline $\mathbf{6 6 - 1 0 0}$ points & 81 & 79 & 68 & 55 & 100 \\
\hline Total: & 100 & 100 & 100 & 100 & 0 \\
\hline
\end{tabular}

Table 8. Pass results for LIT RFL based on the level IV certification sample test

(in \%)

\begin{tabular}{|l|c|c|c|c|c|}
\hline \multirow{2}{*}{ Subtests } & \multicolumn{3}{|c|}{ Results from experimental subgroup 4 } & \multirow{2}{*}{ Results from control sub-group 4 (Russia) } \\
\cline { 2 - 5 } & Ukraine & Kazakhstan & Uzbekistan & Tajikistan & \\
\hline Subtest "Grammar. Vocabulary" & 65 & 68 & 57 & 49 & 100 \\
\hline Subtest "Reading" & 87 & 75 & 64 & 53 & 99 \\
\hline Subtest "Listening" & 83 & 84 & 70 & 59 & 100 \\
\hline Subtest "Writing" & 78 & 78 & 69 & 48 & 97,5 \\
\hline Subtest "Speaking" & 97 & 95 & 86 & 57 & 100 \\
\hline
\end{tabular}

Note: This table shows the percentage of testees who successfully completed the subtests (66\% and above)

Data given in Tables 7 and 8 shows a slight difference in the results that testees achieved when performing the CMM complex model and the level IV certification sample test. The results of the CS testees also differ insignificantly, demonstrating the effectiveness of this model, and the validity of the CMMs, which it presents.

Table 9. Results of the survey for testing centers employees - qualified RFL teachers

(average grade from 1 to 10 )

\begin{tabular}{|l|c|c|c|c|}
\hline Evaluation parameters & CMM - M1 & CMM - M2 & CMM - M3 & CMM - IM \\
\hline Authenticity & 9 & 4 & 9 & 10 \\
\hline Representativeness & 6 & 3 & 7 & 10 \\
\hline Content validity & 5 & 3 & 6 & 10 \\
\hline Construct validity & 4 & 5 & 5 & 8 \\
\hline External validity & 7 & 6 & 8 & 9 \\
\hline Reliability & 3 & 3 & 4 & 9 \\
\hline Adaptability & 4 & 4 & 7 & 9 \\
\hline Efficiency & 6 & 4 & 6 & 8 \\
\hline Consistency & 4 & 5 & 8 & 9 \\
\hline Structural integrity & 4 & 5 & 8 & 10 \\
\hline
\end{tabular}

Legend: CMM - M1 - control-measuring materials, presented in model LIT RFL 1; CMM - M2 - control-measuring materials, presented in model 2; CMM - M3 - control-measuring materials, presented in model 3; CMM - IM - controlmeasuring materials, presented in the complex model.

As seen from the data given in Table 9, the complex model for Russian as a foreign language lingvo-didactic testing has received a high grade from testing centers staff - qualified teachers of RFL. Experts noted the compliance of test situations to the real conditions of communication, the considered reasonable principles for the selection of language, speech and communicative material used in the development of CMMs of this model and furthermore noted the fairly complete coverage of test material and its compliance with the level IV certification of general command of the Russian language. According to employees of testing centers, control-measuring materials presented in this model are characterized by a sufficient degree of reliability, adaptability and efficiency. It is further characterized by systemic and structural integrity. 


\section{Conclusion}

Thus, an analysis of the literature related to the issues of the article, research of goals, the nature and specificity of LIT RFL allows us to offer the following definition of this testological concept: Lingvo-didactic testing of Russian as a foreign language in the form of an interview is a comprehensive criterion-oriented means of measuring the communicative competence of foreigners, realized in the form of special organized discussions on socio-cultural and socio-welfare topics. Intrinsically, LIT RFL corresponds to the modern socio lingvo-cultural realities of the Russian-speaking community. The main features of LIT RFL are the authenticity of the tests, the proximity of test situations to the conditions of natural communication experienced by native Russian speakers.

The study shows that the optional structure of the LIT RFL is a two-stage one. The inclusion of an "admission stage" allows one to reliably measure the level of language competence of testees and consequently accurately determine their level. The second stage, aiming at checking the level of communicative and lingvo-cultural competence formation of the testee is advisable to be organized in the form of a complex conversation, integrating test - reactive replication, test - guided discussion, communicative and situational tasks (cases). The complex structure of the second stage makes it possible to accurately determine whether the testee is able to "freely perceive the socio-cultural and emotional peculiarities of the native speaker's speech, achieve the goals of communication ... and demonstrate a variety of tactics of speech behavior and fluency in the language through means of expression in a variety of lexical and grammatical stylistic, synonymous and structural relations "(On approval of requirements ..., 2014).

\section{References}

Averyanova, G.N., Belikova, L.G., Yerofeyeva, I.N. [and al.] (2000). Sample tests on Russian as a foreign language. General command.. Fourth certification level. St. Petersburg: Zlatoust, 2000. - 134 p.

Andryushina N.P., Vladimirova T.E., Klobukova L.P., Ivanova A.S., Gapochka I.K., Kurylenko V.B. and others. State educational standard of RFL. First level. Second level. Professional modules. - Moscow - St. Petersburg: "Zlatoust", 2000. - 56 p.

Balykhina, T.M., Afanasyeva, I.N., Elnikova, S.I., Ivanova, A.S., Isaev, N.P., Klobukova, L.P., Korchagina, E.L., Kostina, S.G., Rumyantseva, N.M., Stepanenko V.A., Tolstykh, A.A. (2003). State testing of Russian as a foreign language for foreign citizens and stateless persons for admission to the citizenship of the Russian Federation. The sample test on the Russian language. Moscow, PFUR, 2003.

Balykhina, T.M., Rumyantseva, N.M. (2014). Tests on the Russian Language for migrant workers. About life in Russia. Moscow: Drofa. 112.

Balykhina, T.M. (2009). Fundamentals of the theory of tests and practice of testing (in the aspect of Russian as a foreign language). Moscow: Russian language, 2009. - $240 \mathrm{p}$.

Gapochka I.K., Kurilenko V.B., Titova L.A. The requirements for Russian as a foreign language. II level of command oa Russian language in educational, social and professional spheres. Moscow, PFUR, 2005.

State testing of Russian as a foreign language for foreign citizens and stateless persons for admission to citizenship of the Russian Federation. (2003). Moscow: Ministry of Education; 2nd ed.

Dolzhikova, A.V. (2014). Features of legal regulation of lingvo-didactic testing and integration exam for foreign citizens in the Russian Federation. Tambov: Gramota, 2014. №11. Part 1. P. 75-81.

Dolzhikova, A.V., Kozmenko, V.M., Moseikina, M.N., Kiseleva E.V., Kazhaeva O.S. (2014). Integration exam for foreign citizens: foreign experience, problems and prospects of organization in Russia: monograph. Moscow, PFUR, 2014. - 123 p.

A report on the results and main activities of the FMS for 2013 and the planning period of 2014 - 2016. 2014: [Digital resourse]. URL: http://www.fms.gov.ru (date of address: 3.07.2015).

The concept of the state migration policy of the Russian Federation for the period up to 2025 (approved by the. President of Russia June 13, 2012) [Digital resourse]. URL: http://base.garant.ru/ 70188244 / \# text \# ixzz32ngJnNml (date of address: 26.05.2014).

On Amendments to the Regulations on the order of consideration of issues of citizenship of the Russian Federation, approved by Presidential Decree 1325 of November 14, 2002 [Digital resourse]: Presidential Decree number 964 of December 28, 2013 URL: http: //www.consultant .ru / document / cons_doc_LAW_156579.

On Amendments to Article 13.1 of the Federal Law "On the Legal Status of Foreign Citizens in the Russian Federation" and Article 27.2 of the Law of the RF "On Education" [Digital resourse]: Federal Law of November 12, 2012 № 185-FZ .URL: http://www.rg.ru/ 2012/11/14/izmenenniya-dok.html (date of address: 31.07.1204).

On Amendments to the Federal Law "On Citizenship of the Russian Federation" and some legislative acts of the Russian Federation [Digital resourse]: Federal Law of April 20, 2014 № 71-FZ. URL: http://www.rg.ru/2014/04/23/grazhdanstvo-dok.html.

On Amending the Federal Law 'On the Legal Status of Foreign Citizens in the Russian Federation "[Digital resourse]: Federal Law of April 20, 2014 № 74-FZ. URL: http://www.rg.ru/ 2014/04/23 / inostrantsy-dok.html.

On Amendments to the Regulations on the order of consideration of issues of citizenship of the Russian Federation, approved by Presidential Decree of 14 November 2002 № 1325 [Digital resourse]: Presidential Decree 1098 of July 15, 2008 URL: http: // www. rg.ru/2008/07/18/sertifikat-dok.html. 
On Higher and Postgraduate Professional Education (rev. And ext., com. into force on 01.02.2012) [Digital resourse]: The Federal Law of 22.08.1996 № 125-FZ (ed. By 03.12.2011). URL: http://www.consultant.ru/ document / cons_doc_LAW_121834.

On Citizenship of the Russian Federation [Digital resourse]: Federal Law of May 31, 2002 № 62-FZ. URL: http://www.rg.ru/2002/06/ 05/zakon-gragdan.html.

On the formation and work of the commissions for the recognition of a foreign citizen or stateless person a native speaker of the Russian language [Digital resourse]: Order of the Federal Migration Service of Russia of May 26, 2014 № 380. URL: http://www.rg. ru/2014/06/ 20 / komissia-dok.html.

On ensuring inter-ethnic harmony [Digital resourse]: Presidential Decree 602 of May 7, 2012 URL: http://graph.document.kremlin.ru/ page.aspx?1;1610870.

On Education in the Russian Federation (as amended) [Digital resourse]: Federal Law of December 29, 2012 № 273-FZ. URL: http://base.garant.ru/70291362/\#ixzz392thlwlK.

On Approval of the Provision on the order of consideration of issues of citizenship of the Russian Federation [Digital resourse]: Presidential Decree 1325 of November 14, 2002 URL: http://www.fms.gov.ru/documentation/861/details/75197.

On approval of the state testing of foreign citizens and stateless persons in the Russian language as a foreign language [Digital resourse]: Ministry of Education and Science of the Russian Federation (Russian Ministry of Education) № 207of March 24, 2010 URL: http: //www.rg .ru / 2010/05/14 / rustest-dok.html (date of address: 31.07.2014).

On approval of requirements to specialists, members of the Commission for the recognition of a foreign citizen or stateless person a native speaker of the Russian language, the rules of the interview by the commision for the recognition of a foreign citizen or stateless person a native speaker of the Russian language to a foreign national or a stateless person, the requirements for the application form for recognition of a foreign citizen or stateless person a native speaker of the Russian language and the requirements for the form of the commission's decision on the recognition of a foreign citizen or stateless person a native speaker of the Russian language on the recognition of a foreign citizen or stateless person a native speaker of the Russian language [Digital resourse]: Order of the Federal Migration Service of Russia № 379 from 26 May 2014 URL: http://www.garant.ru/hotlaw/ federal/548814.

On approval of the federal government requirements for Russian as a foreign language [Digital resourse]: Ministry of Education and Science of the Russian Federation (Russian Ministry of Education) № 463 of October 28, 2009 URL: http://www.rg.ru/2009/12 /25/yazyk-dok.html.

Sample typical test of Russian as a foreign language for foreign citizens and stateless persons for admission to the citizenship of the Russian Federation. M .: PFUR, 2004.

Official site of the FMS of Russia www.fms.gov.ru.

Information on the migration situation in the Russian Federation for 2013 [Digital resourse]. URL: http://www.fms.gov.ru/about/statistics/ data/details/81106.

How many migrants are in Russia [Digital resourse]. URL: http://www.kommersant.ru/doc/2284497.

Common European Framework of Reference for Languages: learning, teaching, assessment (CEFR), 2001. Common European Framework of Reference for Languages: Learning, Teaching, Assessment. Strasbourg. Department of Language Policy, 2003, Publishing house "Moscow State Linguistic University", Moscow.

Thompson, J. (1990). Experience of the pragmatic test of oral competence: test-interview. Moscow: Russian language abroad, №3, 1990. p. 66-71.

Clark, J.L.D., Clifford, R.T. (1988). The FSILRACTFL proficiency scales and testing techniques: Development, current status, and needed research. - Studies in Second Language Acquisition. 1988. 10, 129-148.

Clark, J.L.D. (1986). A study of the comparability of speaking proficiency interview ratings across three govemment language training agencies. Washington, DS: Center for Applied Linguistics, 1986.

Douglas, D. (1994). Quantity and quality in speaking test performance. Language Testing, 11(2), 125 - 144.

Fulcher, G. (1996). Testing tasks: issues in task design and the group oral. Language Testing, 13(1), 23 - 51.

Hiple, D. V. (1987). The extension of language proficiency guidelines to the less commonly taught languages. // Valdman A. (Ed ) Proceedings of the Symposium on the Evaluation of Foreign Language Proficiency (59-66). Blooming-ton, IN: Indiana University Press.

Language Proficiency Interview. Manual for Testers (2005). Peace Corps Information Collection and Exchange Publication No. T0130. $141 \mathrm{pp}$.

Lazaraton, A. (1996). Interlocutor support in oral proficiency interviews: the case of CASE. Language Testing, 13(2), 151 - 172.

Stansfield, C. W., \& Kenyon, D. M. (1992). The development and validation of a simulated oral proficiency interview. Modern Language Journal, 76(2), 129 - 141.

The Association of Language Testers in Europe [Digital resourse]. URL: http://www.alte.org.

van Lier, L. (1989). Reeling, writhing, drawling, stretching, and fainting in coils: oral proficiency interviews as conversation. TESOL Quarterly, 23(3), 489 - 508.

Wigglesworth, G. (1997). An investigation of planning time and proficiency level on oral test discourse. Language Teaching, 14(1), 85 106.

Young, R. and He, A. W. (1998). Talking and testing: discourse approaches to the assessment of oral proficiency. Amsterdam: John Benjamins Publishing Company. 